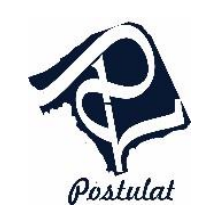

Jurnal Inovasi Pendidikan Matematika

Volume 1, Nomor 1, Juli 2020

\title{
Pengaruh Penggunaan Pop Up Book Sebagai Media Belajar Anak Tunagrahita Ringan Terhadap Kemampuan Membilang Benda di Pusat Kajian dan Pendampingan ABK Universitas Muhammadiyah Gresik
}

\author{
Is Sejati Wuni ${ }^{1}$, Sri Uchtiawati ${ }^{2}$ \\ Pendidikan Matematika, FKIP,Universitas Muhammadiyah Gresik ${ }^{1}$; Jl. Sumatera No. 101 GKB Gresik, Jawa \\ Timur Indonesia 61121; wuni.nugroho@gmail.com \\ Pendidikan Matematika, FKIP,Universitas Muhammadiyah Gresik ${ }^{2}$; Jl. Sumatera No. 101 GKB Gresik, Jawa \\ Timur Indonesia 61121; sri.uchtiawati@umg.ac.id
}

\begin{abstract}
All elements of the Indonesian people are entitled to a proper education without any exception for children with special needs. One classification of children with special needs is children who have mild tunagrahita or include in a category of children with special needs who are able to learn. It can be said like that because they are still be able to learn and receive academic learning such as Science, Language and Mathematic. To facilitate teachers in delivering material to the mild tunagrahita students, teacher can use instructional media when learning process is running. Media that can be used to easiness the teacher in delivering message to the students is using pop-up book. The type of study that the researcherusedisdescriptive quantitative research with pure experimental research method type "Posttest Only Control Design". The subject are mild tunagrahita students from Study and Assistance Center of ABK in Muhammadiyah Gresik Universitywith the total of students is 10 studentswhich are divided into experimental group (Group A) whom they are treated by using pop-up book as media and control group (Group B) which use conventional method in learning process. The data is collected by using documentation and tests. The results of T-Test that is using SPSS 16.0 program showssig value $=0,001$ $<\alpha=0,05$ then Hlis accepted. It can be concluded that there is an effect in the use of pop-up book as media to mild tunagrahita students' ability in counting objects in the Center for Study and Assistance Center of ABK in Muhammadiyah Gresik University.
\end{abstract}

Keywords: Effect, Pop up Book Media, Tunagrahita Students, PKPABK

\begin{abstract}
Abstrak
Semua elemen masyarakat Indonesia berhak memperoleh pendidikan yang layak tidak terkecuali untuk anakanak berkebutuhan khusus. Salah satu klasifikasi anak berkebutuhan khusus yakni anak tunagrahita ringan atau masuk dalam kategori mampu didik. Dikatakan mampu didik karena mereka masih mampu menerima dan melakukan pembelajaran akademik seperti IPA, Bahasa dan Matematika. Materi dasar dalam pembelajaran matematika yang tak lepas dari kehidupan sehari-hari adalah membilang benda. Untuk mempermudah pendidik
\end{abstract}


dalam menyampaikan pesan terhadap anak tunagrahita ringan saat proses pembelajaran pendidik dapat menggunakan mediapembelajaran. Media pembelajaran yang dapat digunakan untuk mempermudah menyampaikan pesan pada peserta didik salah satunya yakni dengan menggunakan media pop up book. Tujuan penelitian ini adalah untuk mendeskripsikan pengaruh penggunaan media pop up book sebagai media belajar anak tunagrahita ringan terhadap kemampuan membilang benda di Pusat Kajian dan Pendampingan ABK Universitas Muhammadiyah Gresik. Jenis penelitian yang digunakan adalah penelitian deskriptif kuantitatif dengan metode penelitian eksperimen murni jenis "Posttest Only Control Design".Subyek dalam penelitian ini adalah anak tunagrahita ringan di Pusat Kajian dan Pendampingan ABK yang berjumlah 10 anak dan terbagi dalam kelompok A atau kelompok eksperimen yaitu kelompok yang mendapatkan perlakuan dengan menggunakan media pop up book dan kelompok B atau kelompok kontrol yaitu kelompok yang menggunakan metode ceramah. Metode pengumpulan data yang digunakan adalah dengan dokumentasi dan tes. Hasil analisis data uji t dengan menggunakan bantuan program SPSS 16.0 menunjukan nilai sig $=0,001<\alpha=0,05$ maka H1diterima, maka dapat disimpulkan bahwa penggunaan media pop up book sebagai media belajar anak tunagrahita ringan berpengaruh terhadap kemampuan membilang benda di Pusat Kajian dan Pendampingan ABK Universitas Muhammadiyah Gresik.

Kata Kunci: Pengaruh, Pop up Book sebagai media belajar, Anak Tunagrahita, PKPABK

INFO ARTIKEL

ISSN $: 2733-0597$
e-ISSN $: 2733-0600$
DOI $\quad:$ http://dx.doi.org/10.30587/postulat.v1i1.1680

Jejak Artikel
Submit Artikel:
3 Mei 2020
Submit Revisi:
17 Juni 2020
Upload Artikel:
26 Juni 2020

\section{A. PENDAHULUAN}

Setiap elemen warga negara berhak untuk memperoleh pendidikan yang layak, tidak terkecuali bagi anak-anak berkebutuhan khusus. Hal ini tertuang dalam Undang-undang Nomor 20 Tahun 2003 Pasal 5 Ayat 3 menyatakan bahwa "Warga negara yang mempunyai kelainan fisik, emosional, mental, Intelektual, dan/atau sosial berhak memperoleh pendidikan khusus.

Salah satu klasifikasi anak berkebutuhan khusus yang memerlukan layanan khusus adalah anak tunagrahita. Tunagrahita adalah individu yang memiliki intelegensi yang signifikan di bawahrata-rata dan disertai dengan ketidakmampuan dalam adaptasi perilaku yang muncul dalam masa perkembangan (Aphroditta, 2012:45). 
Keterbatasan yang dimiliki anak tunagrahita dalam menerima informasi menyebabkan minimnya tingkat pemahaman anak tunagrahita terhadap materi pelajaran yang diberikan. Hal ini dipertegas dengan yang diungkapkan oleh Amin (1995:43) yakni terhambatnya perkembagan kecerdasan anak tunagrahita ringan, memberikan dampak negatif terhadap kemampuan bernalar mereka, disamping itu daya ingat mereka juga lemah, sehingga memiliki keterbatasan dalam berfikir abstrak, kelemahan inilah yang menyebabkan mereka sering mengalami kesulitan dalam belajar, terutama pada bidang mata pelajaran akademik seperti matematika, IPA dan Bahasa.

Membilang benda atau menghitung banyaknya suatu benda merupakan materi dasar dalam pembelajaran matematika yang diperlukan untuk mengembangkan kemampuan matematis dan menumbuh kembangkan keterampilan dalam kehidupan sehari-hari, sehingga apabila kemampuan ini tidak dimiliki atau anak masih mengalami kesulitan, maka anak akan mengalami kendala dalam melakukan aktifitas sehari-hari.

Media merupakan salah satu komponen yang berperan penting dalam keberhasilan suatu pembelajaran. Untuk itu penggunaan dan pemilihan media yang tepat harus dipertimbangkan dan direncanakan secara matang agar dapat sesuai dengan kebutuhan dan kondisi anak, sehingga anak dapat mengerti dan memahami pembelajaran yang disampaikan oleh pendidik sesuai dengan kemampuan dari masing-masing individu.

Salah satu media yang dapat digunakan untuk membantu anak tunagrahita dalam pembelajaran matematika yaitu media pembelajaran tiga dimensi, sebagaimana dijelaskan oleh Masruroh (2017) media tiga dimensi dapat diterapkan dalam meningkatkan hasil belajar matematika anak tunagrahita ringan.Salah satu contoh media tiga dimensi adalah pop uр book. Pop up book adalah sebuah buku yang memiliki bagian yang dapat bergerak atau memiliki unsur tiga dimensi serta memberikan visualisasi yang menarik, mulai dari tampilan gambar yang dapat bergerak ketika halamannya dibuka (Dzuanda, 2011: 1).

Pertanyaan dalam penelitian ini adalah "Apakah penggunaan media pop up book berpengaruh terhadap kemampuan membilang anak tunagrahita ringan di Pusat Kajian dan Pendampingan ABK Universitas Muhammadiyah Gresik?"

\section{B. METODE PENELITIAN}


Is Sejati Wuni ${ }^{1}$, Sri Uchtiawati ${ }^{2}$ : Pengaruh Penggunaan Pop Up Book..........

Jenis penelitian yang digunakan dalam penelitian ini adalah deskriptif kuantitatif dengan metode penelitian ekesperimen murni (True Experimental). Subjek penelitian yang digunakan adalah 10 anak tunagrahita ringan di Pusat Kajian dan Pendampingan ABK Universitas Muhammadiyah Gresik. Subjek penelitian dipilih berdasarkan hasil tes psikologi dengan rata-rata IQ 50-70 dan berusia 12 hingga 15 tahun.

Untuk mengumpulkan data-data yang diperlukan dalam penelitian ini, penulis melakukan metode-metode sebagai berikut metode dokumentasi, yaitu menyelidiki bendabenda tertulis seperti buku-buku, majalah, dokumen, peraturan-peraturan, notulen rapat, catatan harian, dan sebagainya (Arikunto, 2014:201). Metode ini digunakan untuk mendapatkan identitas dan jumlah peserta didik.

Metode tes adalah serentetan pertanyaan atau latihan serta alat lain yang digunakan untuk mengatur keterampilan, pengetahuan, integensi, kemampuan atau bakat yang dimiliki individu/ kelompok (Arikunto, 2014:193). Dalam penelitian ini jenis tes yang digunakan adalah posttest. Posttest digunakan untuk mengambil data kemampuan akhir peserta didik setelah diberikan perlakuan. Posttest berupa tes lisan dan tulis dengan jumlah 13 soal.

Instrumen yang digunakan dalam penelitian ini adalah soal tes lisan dan isian singkat. Tes dibuat dari yang mudah hingga yang sulit untuk menerapkan pemahaman yang runtut. Soal posttest ini sebelumnya telah divalidasi oleh seorang dosen S1 pendidikan matematika FKIP UMG.

Analisis data yang digunakan pada penelitian ini yaitu terhadap hasil posttest yang telah diberikan kepada anak setelah proses pembelajaran dengan menggunakan bantuan program SPSS. Pada tahap ini, langkah awal yang harus ditempuh yaitu melakukan uji normalitas untuk mengetahui apakah sampel yang diambil berasal dari populasi yang berdistribusi normal atau tidak. Jika data berdistribusi normal maka uji hipotesis menggunakan uji t, jika tidak maka data diuji dengan uji mann whitney.

\section{HASIL PENELITIAN}

Data berikut adalah hasil posttest anak tunagrahita ringan di Pusat Kajian dan Pendampingan ABK Universitas Muhammadiyah Gresik. 
Tabel 4.2 Hasil posttest kelompok eksperimen

\begin{tabular}{|c|l|c|}
\hline No & \multicolumn{1}{|c|}{ Nama } & Nilai \\
\hline 1 & HDA & 99 \\
\hline 2 & IHR & 96 \\
\hline 3 & ARP & 100 \\
\hline 4 & ADK & 90 \\
\hline 5 & MFDK & 97 \\
\hline
\end{tabular}

Tabel 4.3 Hasil posttest kelompok kontrol

\begin{tabular}{|c|l|c|}
\hline No & \multicolumn{1}{|c|}{ Nama } & Nilai \\
\hline 1 & MAN & 70 \\
\hline 2 & RF & 78 \\
\hline 3 & MR & 76 \\
\hline 4 & UM & 91 \\
\hline 5 & SRK & 80 \\
\hline
\end{tabular}

Dengan data tersebut, maka selanjutnya dilakukan uji normalitas untuk mengetahui apakah sampel yang dipilih berasal dari populasi yang berdistribusi normal. Jika data berdistribusi normal maka selanjutnya dilakukan uji hipotesis dengan menggunakan uji-t. Namun jika data tidak berasal dari populasi yang berdistribusi normal, maka uji hipotesis menggunakan uji Mann-whitney.

Pada penelitian ini, uji normalitas dilakukan dengan menggunakan program SPSS 16.0 yaitu dengan uji normalitas Lilliefors (Kolmogrov-Smirnov). Adapun langkah-langkahnya adalah sebagai berikut:

1. Menentukan hipotesis

$H_{0}$ : sampel berasal dari populasi yang berdistribusi normal

$H_{1}$ : sampel berasal dari populasi yang berdistribusi tidak normal 
2. Menentukan taraf signifikan $\alpha=0,05$

3. Menentukan kriteria

$H_{0}$ : diterima jika sig (P-value) $>\alpha$

$H_{1}$ : diterima jika sig $(\mathrm{P}$-value $) \leq \alpha$

4. Melakukan perhitungan uji normalitas dengan Lilliefors (Kolmogrov-Smirnov) dengan menggunakan bantuan program SPSS 16.0

5. Menarik kesimpulan

Tabel 4.4 Banyak data yang diuji

\begin{tabular}{|l|c|c|c|c|c|l|}
\hline \multirow{2}{*}{} & \multicolumn{6}{|c|}{ Cases } \\
\cline { 2 - 8 } & \multicolumn{2}{|c|}{ Valid } & \multicolumn{2}{|c|}{ Missing } & \multicolumn{2}{|c|}{ Total } \\
\cline { 2 - 8 } & $\mathrm{N}$ & Percent & $\mathrm{N}$ & Percent & $\mathrm{N}$ & Percent \\
\hline Kelas Kontrol & 5 & $100.0 \%$ & 0 & $.0 \%$ & 5 & $100.0 \%$ \\
\hline Kelas & 5 & $100.0 \%$ & 0 & $.0 \%$ & 5 & $100.0 \%$ \\
\hline
\end{tabular}

Dari tabel 4.4 dapat dilihat banyaknya data yang dianalisis pada kelas kontrol dan kelas eksperimen sama, yaitu berjumlah 5 peserta didik.

Tabel 4.5 Hasil Uji Normalitas

\begin{tabular}{|l|c|c|c|c|c|c|}
\hline \multirow{2}{*}{} & \multicolumn{3}{|c|}{ Kolmogorov-Smirnov ${ }^{\mathrm{a}}$} & \multicolumn{3}{|c|}{ Shapiro-Wilk } \\
\cline { 2 - 7 } & Statistic & Df & Sig. & Statistic & Df & Sig. \\
\hline Kelas & .248 & 5 & $.200^{*}$ & .944 & 5 & .692 \\
Kontrol & & & & & & \\
\hline Kelas & .259 & 5 & $.200^{*}$ & .888 & 5 & .345 \\
\hline
\end{tabular}

a. Liliefors Significance Correction

Dari tabel 4.5 dapat dilihat pada kolom sig untuk uji Lilliefors (Kolmogrov-Smirnov) kelas kontrol dan kelas eksperimen ( $\operatorname{sig}=0,200>\alpha(\alpha=0,05))$, maka $H_{0}$ diterima. Sehingga dapat disimpulkan data sampel dari populasi yang berdistribusi normal.

Uji hipotesis digunakan untuk mengetahui apakah media popup book berpengaruh terhadap kemampuan membilang benda anak tunagrahita ringan. Berdasarkan hasil uji 
normalitas diketahui bahwa data posttest membilang benda dari kelas eksperimen dan kelas kontrol berdistribusi normal, maka uji hipotesis yang digunakan adalah uji t. Pada penelitian ini, perhitungan uji t dilakukan dengan bantuan program SPSS 16.0. Adapun langkahlangkah untuk melakukan perhitungan uji t adalah sebagai berikut:

1. Merumuskan hiipotesis

$H_{0}: \mu_{1} \leq \mu_{2}$ Artinya, kemampuan membilang benda anak tunagrahita ringan yang menggunakan popupbook sebagai media belajar anak kurang baik atau sama dengan kemampuan membilang benda anak tunagrahita ringan yang tidak menggunakan popup book sebagai media belajar.

$H_{1}: \mu_{1}>\mu_{2}$ Artinya, kemampuan membilang benda anak tunagrahita ringan yang menggunakan popup book sebagai media belajar lebih baik dari kemampuan membilang benda anak tunagrahita ringan yang tidak menggunakan popup book sebagai media belajar.

2. Menentukan taraf signifikan $\alpha=0,05$

3. Melakukan perhitungan dengan menggunakan bantuan program SPSS 16.0

4. Menentukan kriteria

$H_{0}$ : ditolak jika sig (P-value) $<\alpha$

$H_{1}$ : ditolak jika sig (P-value) $\geq \alpha$

5. Menarik kesimpulan

Media popup book dikatakan berpengaruh terhadap kemampuan membilang benda anak tunagrahita ringan jika $H_{0}: \mu_{1}>\mu_{2}$.

Tabel 4.6 Hasil uji t

\begin{tabular}{|l|c|c|}
\hline Levene's & \\
Test for & \\
Equality of & \\
Variances & t-test for Equality of Means \\
\hline
\end{tabular}


Is Sejati Wuni ${ }^{1}$, Sri Uchtiawati ${ }^{2}$ : Pengaruh Penggunaan Pop Up Book..........

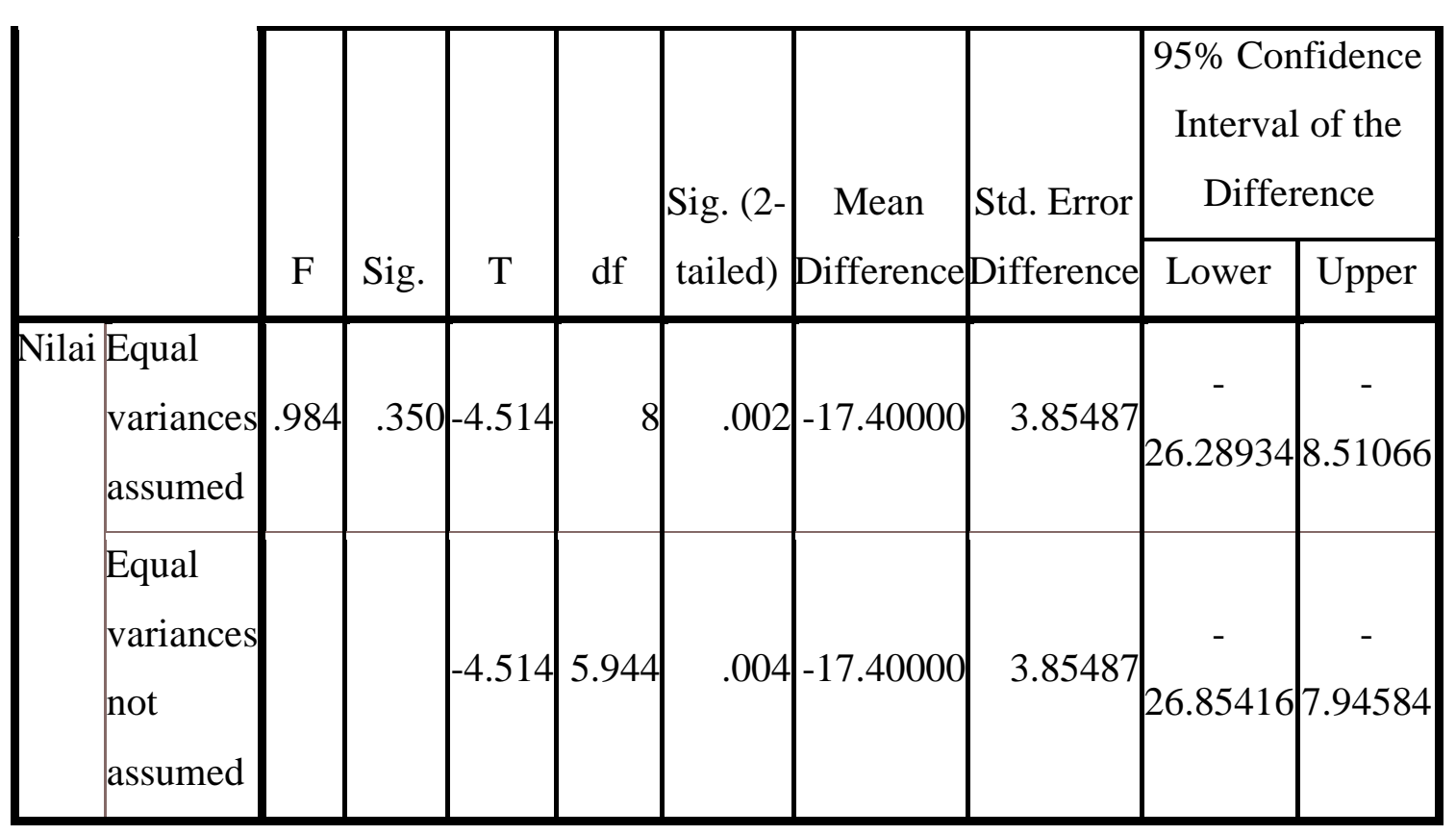

Dari tabel 4.8 dapat dilihat pada uji Levene's Test nilai sig $=0,350>\alpha(\alpha=0,05)$ maka dapat disimpulkan bahwa kedua sampel homogen. Dikarenakan data homogen maka uji t menggunakan nilai sig (2-tailed) Equal variances assumed. Hasil uji t menunjukkan sig (2tailed) $=0,002$. Karena $H_{0}$ menandakan uji satu sisi maka nilai sig dibagi 2 menjadi sig (1tailed $)=\frac{\operatorname{sig}(2-\text { tailed })}{2}=\frac{0,002}{2}=0,001 . P$-value $($ sig $)=0,001<\alpha(\alpha=0,05)$.

\section{KESIMPULAN, DISKUSI DAN REKOMENDASI}

Berdasarkan hasil analisis data yang telah dilakukan oleh peneliti, maka jawaban dari rumusan masalah pada penelitian ini yaitu hasil belajar peserta didik tunagrahita dengan menggunakan pop up book sebagai media belajar anak lebih baik dibandingkan hasil belajar peserta didik tunagrahita tanpa menggunakan media pop up book sebagai media belajar. Sehingga dapat diambil kesimpulan bahwa penggunaan media pop up book berpengaruh terhadap kemampuan membilang benda anak tunagrahita ringan di Pusat Kajian dan Pendampingan Anak Berkebutuhan Khusus.

\section{E. DAFTAR PUSTAKA}

Arikunto, Suharsimi. (2014). Prosedur Penelitian. Jakarta: Rineka Cipta Abdurrahman, Mulyono. (1994). Pendidikan Bagi Anak Berkesulitan Belajar. Jakarta: 


\section{Rineka Cipta}

Amin, Moh. (1995). Ortopedagogik Anak Tunagrahita. Bandung: Depdikbud Dirjen Pendidikan Tinggi Proyek Pendidikan Guru.

Anas, Sudijono. (2009). Pengantar Evaluasi Pendidikan. Jakarta: PT Raja Grafindo Persada. Aphroditta. 2012. Panduan Lengkap Orangtua \& Guru untuk Anak dengan Disleksia (Kesulitan Membaca). Jogjakarta: Javalitera.

Apriyanto, Nunung. (2012). Seluk-beluk Tunagrahita \& Strategi Pembelajarannya. Jogjakarta: Javalitera.

Arief S Sadiman dkk. (2006). Media Pendidikan. Jakarta: PT Raja Grafindo Persada.

Arsyad, Azhar. (2010). Media Pembelajaran. Jakarta: PT Raja Grafindo Persada.

Astati. (1995). Terapi Okupasi, Bermain dan Musik untuk Anak Tunagrahita. Jakarta: Debdikbud.

Bernadette, Puleo. (2010). Next Stop: Pop-ups The Influence of Paper Engineering on Visual Media. [online]. Tersedia:http://www.popuplady.com/pdf/BernadetteThesisHx.pdf [diakses tanggal 21 Maret 2018]

Burhan Bungin. (2005). Metodologi Penelitian Kuantitatif: Komunikasi, Ekonomi, dan Kebijakan Publik Serta Ilmu-Ilmu Sosial Lainnya. Jakarta: Kencana

Dzuanda. (2011). Perancangan Buku Cerita Anak Pop up Tokoh-tokoh Wayang Berseri: Seri Gatotkaca. Jurnal. Institut Teknologi Sepuluh November

Efendi, Mohammad. (2006). Pengantar Psikopedagogik Anak Berkelainan. Jakarta: Bumi Aksara.

Fatimah. (2009). Peningkatan Kemampuan Mengenal Bilangan pada Anak Usia Dini melalui Penggunaan Media Balok. Jurnal. Bandung: FIP UPI

Kustandi, Cecep dkk. (2011). Media Pembelajaran Manual dan Digital. Bogor: Ghalia Indonesia

Lexy J. Moleong. (2010). Metodologi Penelitian Kualitatif. Bandung: Remaja Rosdakarya Masruroh Siti. (2017). Penerapan Media Tiga Dimensi Terhadap Hasil Belajar Matematika Anak Tunagrahita Ringan. Jurnal. Program Studi Pendidikan Luar Biasa Fakultas Ilmu Pendidikan Universitas Negri Surabaya

Mulyasa, E. (2004). Kurikulum Berbasis Kompetensi. Bandung: Remaja Rosda Karya. 
Is Sejati Wuni ${ }^{1}$, Sri Uchtiawati ${ }^{2}$ : Pengaruh Penggunaan Pop Up Book..........

Mumpuniarti. (2007). Pendekatan Pembelajaran Bagi Anak Hambatan Mental. Yogyakarta: Kanwa Publisher.

Munzayanah. (2000). Tunagrahita. Depdikbud. UNS Surakarta

Nazir. (2013). Metode Penelitian. Bogor: Ghalia Indonesia.

Negoro dan B. Harahap. (1998). Ensiklopedia Matematika. Jakarta: Ghalia.Indonesia

Oemar Hamalik. (1989). Media Pendidikan. Bandung: Citra Aditya.

Republik Indonesia. (2003). Undang-undang No.20 Tahun 2003 tentang sistem pendidikan nasional. Lembaran Negara RI Tahun 2003, No. Sekretariat Negara. Jakarta.

Shaleh, Abdul Rachman. (2004). Madrasah dan Pendidikan Anak Bangsa (Visi, Misi, dan Aksi). Jakarta: PT Raja Grafindo Persada

Sedarmayanti. (2009). Sumber Daya Manusia dan Produktivitas Kerja. Bandung: Mandar Maju

Semiawan, C.R. \& Mangunsong F. (2010). Keluarbiasaan Ganda. Jakarta: Kencana Prenada.

Sholikhah Aimatus. (2017). Pengembangan Media Pop Up Book untuk Meningkatkan Kemampuan Menulis Kreatif pada Mata Pelajaran Bahasa Indonesia Materi Menulis Karangan Kelas V SDN Rowoharjo. Jurnal. Program Studi Pendidikan Guru Sekolah Dasar Fakultas Keguruan Ilmu Pendidikan.

Slavin, Robert E. (1994). Cooperative Learning, Teori, Riset dan Praktik. Penterjemah: Bandung: Nusa Media

Sudjana, Nana. (1990). Teori-teori Belajar Untuk Pengajaran. Bandung: Fakultas Ekonomi UI.

Sudjana, Nana dan Ahmad Rivai. (2002). Media Pengajaran. Bandung:Sinar Baru Algesindo.

Suranto, Soedarini. (2002). Kemampuan Merawat Diri. Jakarta: Depdikbud

Tim Penyusun Kamus Pusat Bahasa. 2002. Kamus Besar Bahasa Indonesia. Edisi ke-3, Cetakan ke-2. Jakarta: Balai Pustaka.

Yamit, Zulian. (2003). Manajemen Produksi dan Operasi. Yogyakarta: Ekonisia: FE UII.

Yusufhadi Miarso. (2004). Menyemai Benih Teknologi Pendidikan. Jakarta: Pustekkom. 
Yusuf, Munawir dkk. (2003). Pendidikan bagi Anak dengan Problema Belajar. Solo: Tiga Serangkai Pustaka Mandiri. 